\title{
Katla KJaRTansdóttir
}

\section{„Af hverju fæe ég ekki að kynna safnið mitt í sjónvarpinu? “ \\ Stutt greinargerð um Íslenska dýrasafnið}

\section{Upphafið}

Í greininni verður fjallað um sögu Íslenska dýrasafnsins, hlutverk pess og viðtökur safngesta. Íslenska dýrasafnið opnaði vorið 1970 í Breiðfirðingabúð á Skólavörðustíg og voru par til sýnis á annað púsund uppstoppuð dýr af margvíslegu tagi. Stofnandi safnsins, Kristján S. Jósefsson, greinir frá pví að safnið hafi fyrst opnað í gamla Búnaðarfélagshúsinu pann 22. ágúst 1969 en síðan hafi pað flust í menntaskólahúsið par sem pað var starfrækt í einn vetur og að lokum opnaði pað svo í Breiðfirðingabúð. Í tengslum við áhuga sinn á pessu viðfangsefni viðhefur Kristján engar vífilengjur. Í viðtali við blaðamann Tímans segir forstöðumaðurinn svo frá:

En pegar ég var í Hofteigi, datt með mig hestur, svo ég meiddist, handleggsbrotnaði og fleira, og var pví frá vinnu árlangt eða vel pað. En upp úr pví fór ég til Reykjavíkur og var einn vetur gæzlumaður á Kleppi. En paðan fór ég norður í Eyjafjörð og vann pá í Kaupangi, par sem Björn Ingvarsson lögfræðingur rak pá bú. Síðan réð ég mig á fiskibát frá Akureyri, og var svo aðallega við sjómennsku á ýmsum skipum nokkrar vertíðir. Eftir petta varð ég handlangari hjá múrara, pað mun hafa verið upp úr 1947. Svo ílengdist ég í múrverkinu og vann við pað hér og par austanfjalls nokkur ár. Og við pað vann ég austur í Hrunamannahreppi, pegar

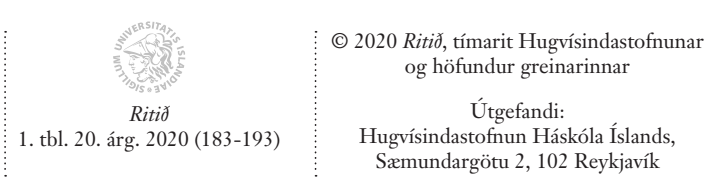

Birtist á vefnum http://www.ritid.hi.is. Tengiliður: ritið@hi.is

DOI: $10.33112 /$ ritid.20.1.9

Birt samkvæmt skilmálum Creative Commons BY (4.0). 
hugur minn fór að snúast um uppsett dýr. Sú hugsun varð svo áleitin, að síðan hefur hún ráðið lífi mínu. ${ }^{1}$

Ljóst er að safnið og uppstoppuðu dýrin hafa átt hug forstöðumannsins allan og athyglisvert er hversu sterkt hann tekur til orða í pessu samhengi. Velta má fyrir sér hvort pakka beri hestinum, sem fleygði honum af baki, pennan eldheita áhuga fyrir uppstoppuðum dýrum. Eitt er víst að Kristján sinnti safninu af mikilli alúð og hafði augljóslega mikinn metnað fyrir starfsemi pess. Við sjáum líka á peim myndum sem aðgengilegar eru á vef Ljósmyndasafns Reykjavíkur, og fylgja sumar pessari grein, að safngestir hafa margir hverjir heillast verulega af dýrunum. Á meðfylgjandi mynd sjáum við til dæmis sjá unga stúlku sem horfir dreymnum augum upp til hvíta svansins við hlið hennar, sem vissulega er glæsilegur á að líta.

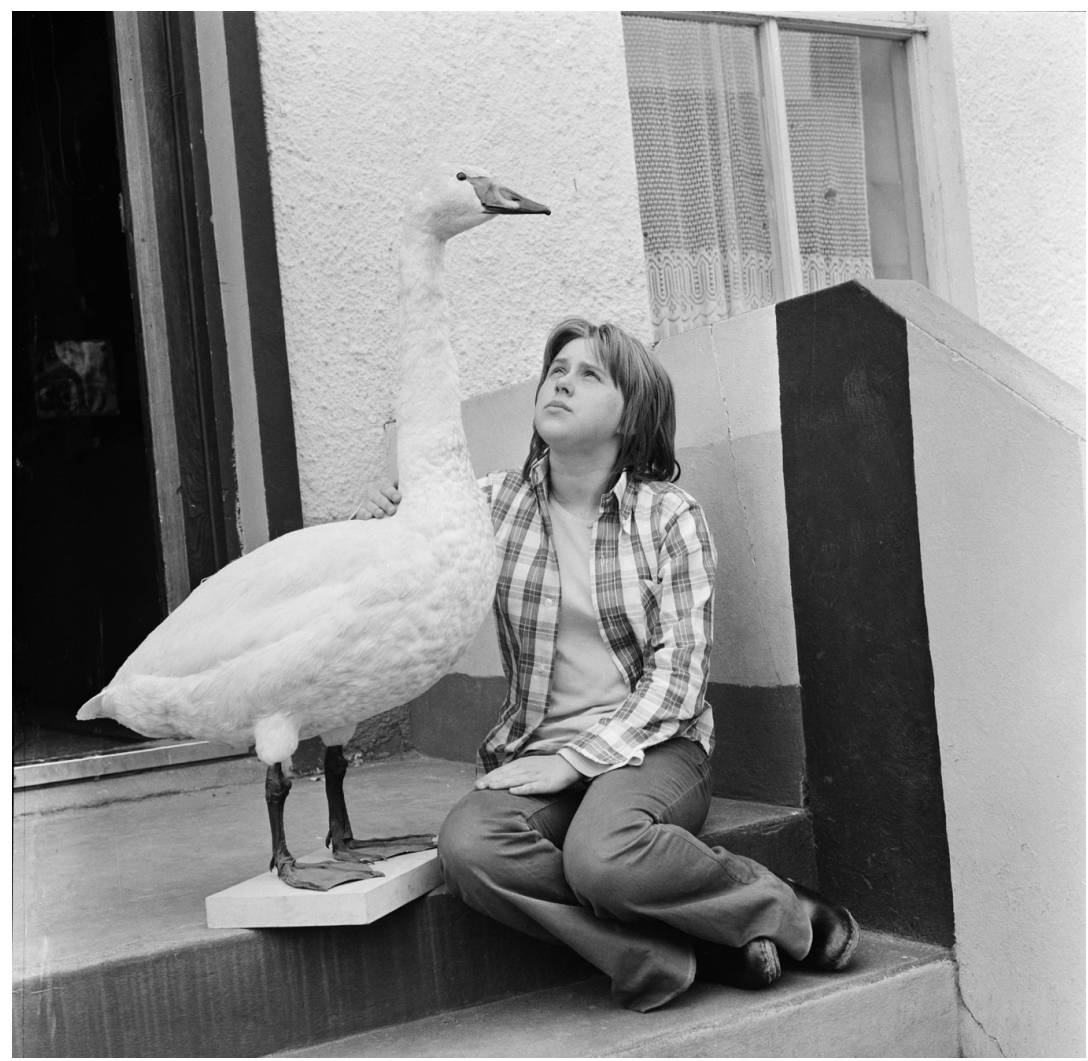

Stúlka á tröppum með uppstoppaðan svan.

1 H. Kr., „Safnið ætti að hafa talsverðu hlutverki að gegna í borg eins og Reykjavík“, Timinn, 17. mars 1974, bls. 11. 
Forstöðumaður íslenska dýrasafnsins Kristján S. Jósefsson er langt frá pví að vera sá eini sem laðast hefur að kynlegum (eða tignarlegum) uppstoppuðum dýrum. Lista- og fræðimenn á borð við pau Bryndísi Snæbjörnsdóttur og Mark Wilson má nefna í pessu samhengi. Listrannsókn peirra á menningarsögu og framhaldslífi 34 uppstoppaðra ísbjarna í Bretlandi er líka gott dæmi um hversu margvíslegar merkingar og heillandi frásagnir er oft að finna í gripum af pessu tagi. ${ }^{2}$ Pegar farið er að kafa dýpra undir feld (eða hami) getur margt áhugavert komið ljós. Í bók sinni The Breathless Zoo fjallar Rachel Poliquin einnig um petta kynngimagnaða aðdráttarafl sem gripir af pessu tagi hafa oft til að bera. ${ }^{3}$ Með lífleysi sínu geta peir vissulega stundum vakið óhug en jafnframt hvílir yfir peim einhvers konar dulmagn, sem ekki er alltaf auðvelt að skýra í hverju liggur.

Velpekkt greining Donnu Haraway á uppstoppuðum afrískum dýrum í bandaríska Náttúruminjasafninu í New York borg sýnir einnig vel hversu hápólitískar og orðræðustýrandi sýningar af pessu tagi geta verið. Að hennar mati varpar sýningin á afrísku dýrunum í sal Akley’s ljósi á margvísleg flókin menningarleg tengsl og tekur jafnframt pátt í að setja fram ákveðna ímynd af Afríku sem framandi og villtu svæði. Ímynd sem hins vegar á sér kannski litla sem enga stoð í raunveruleikanum. ${ }^{4}$ Í pessu samhengi er áhugavert að velta fyrir sér hvers konar framsetning af Íslandi, eða íslenskri náttúru, birtist á hinu íslenska dýrasafni Kristjáns S. Jósefssonar í Breiðfirðingabúð. Hvaða ímynd af landi, pjóð og dýrum, í hugum safngesta og ferðamanna, tók sýningin pátt í að skapa?

Á myndinni hér á eftir sést til dæmis hvernig dýrunum er stillt fram í einhvers konar tilbúnu vetrarríki, par sem snjór er í fjöllum og á jörðu. Hjá erlendum ferðamönnum hefur pessi framsetning eflaust fallið vel að hugmyndum peirra um Ísland, sem kannski hálfvillt og nær óspillt landsvæði. Pá eru dýrin sjálf í sínum vetrarklæðum og falla pví (eins og í náttúrunni) ágætlega að hvítu „landslaginu“ sem eykur á áhrif, undirtóna eða loforð um hreinleika náttúrunnar. Í forgrunni myndar stingur pó örlítið í stúf staur sem virðist hulinn plasti. Hvaða tilgangi honum er ætlað að pjóna er erfitt að dæma um en djúphugull safngestur gæti ef til vill velt fyrir sér áhrifum plastmengunar á náttúru og auðlindir landsins.

2 Bryndís Snæbjörnsdóttir og Mark Wilson, Nanoq: Flat Out and Bluesome: a Cultural Life of Polar Bears, London: Black Dog Publishing, 2006.

3 Rachel Poliquin, The Breathless Zoo: Taxidermy and the Cultures of Longing, University Park, PA: Pennsylvania State University Press, 2012.

4 Donna J. Haraway, ,Teddy bear patriarchy: Taxidermy in the garden of Eden, New York City, 1908-1936“, Social Text 11/1985, bls. 20-64. 


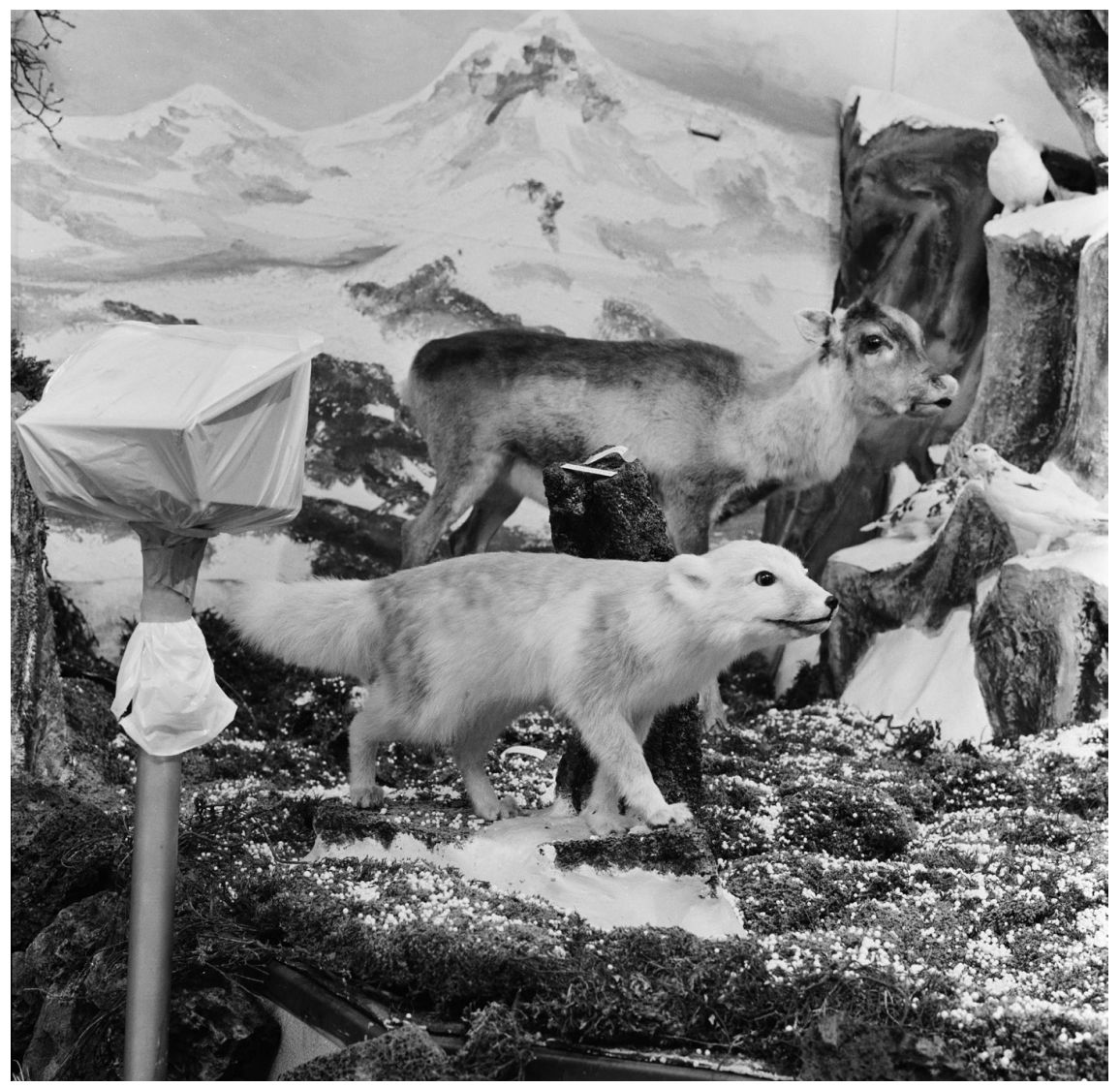

Uppstoppaður refur, rjúpur og hreindýr. Ljósmyndasafn Reykjavíkur.

Gripir af pessu tagi eru pó langt frá pví að vera einhamir og geta peir auðvitað vakið mjög mismunandi spurningar í hugum hvers og eins. Pá getur einn og sami gripurinn falið í sér margvíslegar ólíkar frásagnir og merkingarauka - allt eftir samhengi og mismunandi framsetningarmáta. Pegar kafað er ofan í undirlögin má jafnvel finna fyrir pversagnakenndri stöðu safnmuna af pessu tagi. Óneitanlega er um að ræða steindauð dýr sem pó er ætlað að gefa einhvers konar lifandi innsýn í samhengi náttúrunnar og samband manneskjunnar við aðrar dýrategundir. Раð hvernig gripir af pessu tagi eru settir fram er hins vegar lykilatriði ef ætlunin er að virkja pá til samtals. Mögulega geta slíkir munir verið öflug tæki sem nýta má til dæmis pegar kemur að pví að vekja fólk til umhugsunar um umhverfismál eða jafnvel tegundamissi. ${ }^{5}$ Í pessu samhengi er vert að geta pess hvernig

5 Katla Kjartansdóttir, „The changing symbolic meaning of the extinct great auk and 
munir af pessu tagi fela oft í sér einhvers konar húmor eða jafnvel íroníska undirtóna. Pannig sjáum við til dæmis gripunum beitt í kvikmyndinni með Allt á breinu frá árinu 1982 par sem Stuðmenn sjást bregða á leik innan um dýrin á íslenska dýrasafninu í Breiðfirðingabúð. Á myndum sem er að finna á vef Ljósmyndasafns Reykjavíkur (og fylgja sumar pessari grein) má einnig sjá hvernig safnið varð við ákveðin tækifæri vettvangur fyrir bæði börn og fullorðna til að gantast og bregða á leik.

Á einni slíkri mynd sjást uppstoppaðar kindur, börn og (mögulega uppstoppaður) jólasveinn í fullum skrúða. Af svip barnanna að dæma ríkti við petta tækifæri blanda af kátínu, forvitni, óhug og gleði í hópnum. Peir sem eldri eru horfa í myndavélina nokkuð kaldir á svip en hinir yngri hafa augljóslega gaman af pessu uppátæki. Önnur mynd sýnir forstöðumanninn sjálfan standa prúðbúinn, í jakkafötum og með bindi, við stæðilegan, íslenskan hest og á baki hans situr glaðleg stúlka sem virðist mjög lukkuleg. Við hlið hestsins stendur svo önnur stúlka sem bíður pollróleg eftir pví að fá að bregða sér á bak.

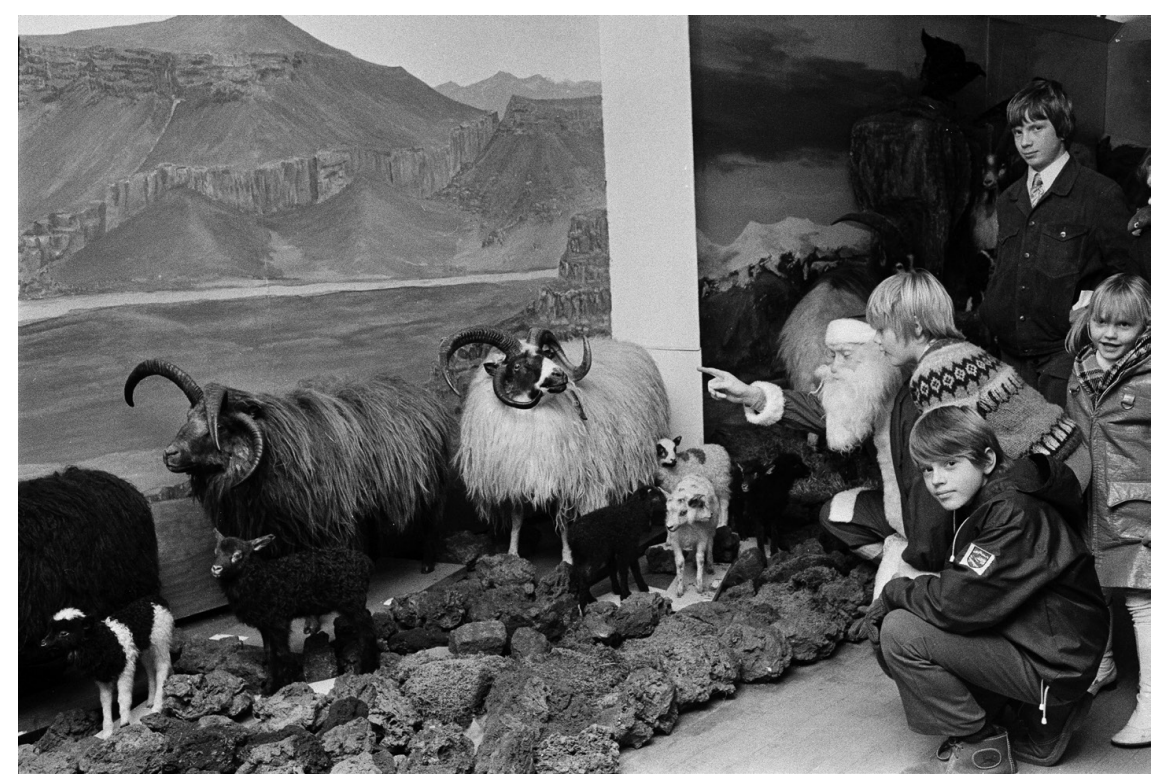

Uppstoppaðar kindur, börn og jólasveinn. Ljósmyndasafn Reykjavíkur.

its afterlife as a museum object at the Natural History Museum of Denmark“, ritstj. Brita Brenna, Nordisk Museologi 2/2019, bls. 41-56. Í pessari grein fjallar höfundur meðal annars um pað hvernig geirfuglinn sem safngripur hefur verið virkjaður í tengslum við slík málefni á danska Náttúruminjasafninu í Kaupmannahöfn. 
Íslenska dýrasafnið og saga pess vekur óneitanlega upp spurningar um hið margslungna og flókna samband manna og dýra. Í bók sinni The PostModern Animal ræðir Steve Baker um hvernig menning mótar skilning og túlkun okkar á dýrum, rétt eins og dýr hafa áhrif á túlkun okkar á menningu. Hugmyndir okkar um dýr hafa pannig jafnframt áhrif á hugmyndir okkar um mannlegt samfélag og hlutverk manneskjunnar í veröldinni. ${ }^{6}$ Í pessu samhengi er vert að nefna hvernig menningarleg framsetning á dýrum, til dæmis í kvikmyndum, listum, pjóðsögum og á söfnum, varpar fyrst og fremst ljósi á mannlegan skilning á dýrum og hlutverk peirra í samfélagi manna. Uppstoppuðu dýrin í Breiðfirðingabúð eru vissulega einnig afurðir ákveðinnar menningarsköpunar. Framsetning peirra á safninu og menningarlegt samhengi vekur upp flóknar spurningar er varða tengsl manna við dýr en ekki síður hið dýrslega í mennskunni.

\section{Arin verkefni}

Varðandi verkefni safnsins segir Kristján, í fyrrnefndu viðtali við blaðamann Timans, að pau séu vissulega ærið mörg og að safnið pyrfti í raun að hafa burði til að ráða fagmann í fast starf. Hann tekur jafnframt fram að pað séu ýmsir skólamenn, víðsvegar um land, sem hafi áhuga fyrir vísi að náttúrugripasafni við skólana sína og vilji jafnvel fá fugla setta upp í pví sambandi. Til viðbótar nefnir hann svo pá staðreynd að pað séu:

ýmsir einstaklingar, sem vilja fá sitthvað gert, langar til að eiga fugl eða aðrar skepnur eða haus af kind eða kú. Pað er hérna listi yfir pannig verkefni, sem hér liggja fyrir eins og sakir standa. Hér er pví ærið verk að vinna, til að fullnægja eftirspurninni á pessu sviði innanlands. Auk pess hef ég rökstuddan grun, eða jafnvel vissu studda fenginni reynslu fyrir pví, að pað gæti verið nokkur markaður fyrir íslenzk dýr uppsett til útflutnings. Hér eru vissulega mörg verkefni fyrir höndum. ${ }^{7}$

Engum blöðum er um pað að fletta að forstöðumaðurinn hefur haft mikla trú á íslenska dýrasafninu, hlutverki bess og framtíð. Jafnframt er ljóst að miðlunargildi safnsins er í hans huga ótvírætt og verkefnin brýn, jafnt innanlands sem utan.

6 Steve Baker, The Post-Modern Animal, London: Reaktion Books Ltd., 2000.

7 H.Kr., „Safnið ætti að hafa talsverðu hlutverki að gegna í borg eins og Reykjavík“, bls. 11 . 


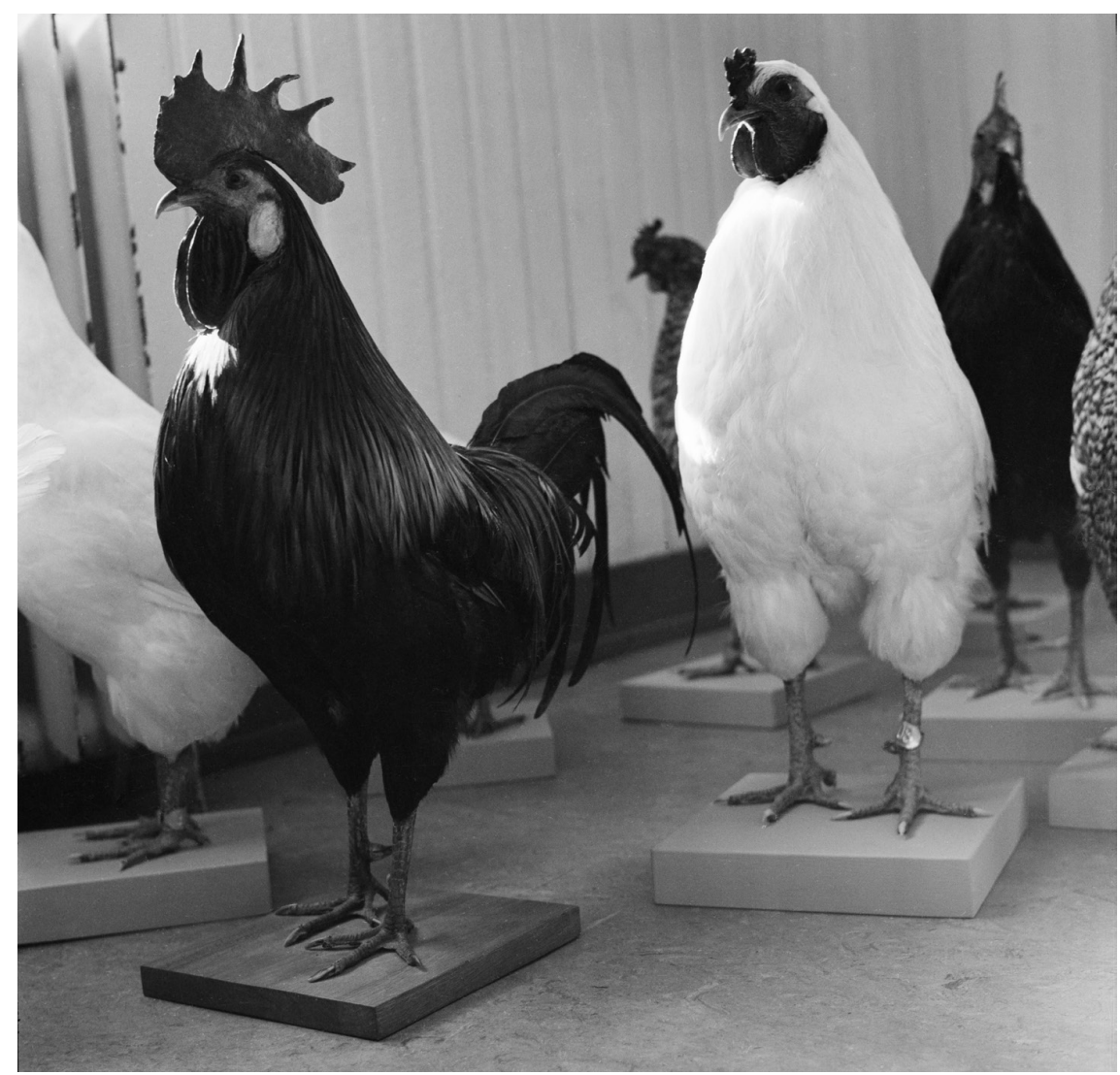

Uppstoppaðar hænur. Ljósmyndasafn Reykjavíkur.

\section{Uppgangur safnsins og ný beyrnarteki}

Pegar flett er í gegnum umfjöllun og fréttir um safnið kennir ýmissa grasa. Í Dagblaðinu, miðvikudaginn 22. mars árið 1978, birtist umkvörtun eigandans undir yfirskriftinni „Af hverju fæe ég ekki að kynna safnið mitt í sjónvarpinu?" Svo virðist sem Kristján sé afar ósáttur við pað að slíkri beiðni hafi ítrekað verið hafnað og hringir pví til blaðsins umræddan dag til að varpa fram pessari spurningu og ræða röksemdir fyrir umleitan sinni. Í tengslum við pessa umræðu segir hann meðal annars: „Nú er mér spurn hvers á íslenzka dýrasafnið að gjalda. Eina safnið sinnar tegundar, að pví er ég tel, hér á landi. Dýrasafn par sem komnir eru á annað púsund safngripir. Má ekki segja frá slíku framtaki í sjónvarpinu? “8

8 Ólafur Geirsson, „Af hverju fæ ég ekki að kynna safnið mitt í sjónvarpinu?“, Dagblaðið, 22. mars 1978, bls. 3. 
Í sömu umfjöllun Dagblaðsins um safnið segir að nú hafi dýrin í Breiðfirðingabúð fengið málið. Gestir safnsins geti nefnilega fengið lánuð heyrnartæki, sem stungið er í samband við lítið tæki við hvern bás og heyrist pá mál viðkomandi dýrs. Einnig fylgi með stutt frásögn um dýrið. Ennfremur er tekið fram að dýramálinu sé stjórnað frá miklu stjórnborði og að allt að 13 manns geti hlustað á mál dýranna í einu. Í sömu frétt segir jafnframt frá pví að ekki hafi bæst við ný dýr í safnið nokkuð lengi, en pað eigi pó í pöntun ein 500 stykki, meðal annars hval og 5 ára gamalt naut. Að lokum er vakin athygli á pví hversu ferðamannahópar hafi í raun sinnt safninu lítið sem ekkert og tekið fram að ástæða pess sé líklega sú að leiðsögumenn virðist ekki telja pað nægilega merkilegt fyrir útlendinga. Í greininni er beinlínis bent á að petta ættu ferðaskrifstofur að taka til athugunar og er svo að lokum áréttað að safnið sé opið alla daga frá 10-22. ${ }^{9}$

Að öðru leyti virðist sem safnið hafi verið nokkuð vinsælt og vel nýtt af margvíslegum hópum. Í Askunni árið 1978 er meðal annars sagt frá pví að krakkar frá Blindraskólanum heimsæki safnið reglulega. ${ }^{10}$ Valgeir Gestsson, formaður Sambands grunnskólakennara, minnist einnig á safnið í umfjöllun í Pjódviljanum árið 1978 en hann telur safnið hafa margvíslega góða kosti pegar kemur til dæmis að kennslu grunnskólabarna. Máli sínu til stuðnings segir hann:

Uppstoppuð dýr eru ákaflega hentug kennslutæki fyrir börn á grunnskólastigi. Fyrir börn hér á Reykjavíkur-svæðinu væri auðvitað æskilegt að pau kynntust dýrunum lifandi, en pað er skárri kostur en enginn, að pau hafi aðgang að pví að sjá dýrin uppstoppuð. ${ }^{11}$

Valgeir Gestsson vekur hér máls á mikilvægi pess að pau skólabörn í borginni sem ekki hafi aðgang að lifandi dýrum fái pó alla vega að nálgast pau uppstoppuð á dýrasafninu. Í gegnum tíðina hafa hinir ýmsu fræðimenn beint sjónum að pví með hvaða hætti bæði lifandi og uppstoppuðum dýrum á söfnum, sýningum og í dýragörðum var ætlað að uppfræða íbúa borga og bæja um náttúruna. Dýragarðar og náttúruminjasöfn spruttu upp eins og gorkúlur í flestum borgum Evrópu í lok 19. aldar og urðu fljótt vinsælir viðkomustaðir, til fræðslu og skemmtunar fyrir bæði fullorðna og börn. Söfn

9 H.Kr., „Safnið ætti að hafa talsverðu hlutverki að gegna í borg eins og Reykjavík“, bls. 11.

10 „Pannig lítur Súsanna á heiminn“, Eskan 7-8/1. júlí 1978, bls. 14.

11 „Megum ekki við pví að missa safnið“, Pjóoviljinn, 7. september 1978, bls. 11. 
af pessu tagi taka í raun við af furðukamesum upplýsingarinnar á borð við safn Ole Worm, par sem nokkuð var um uppstoppuð dýr í bæði heilu lagi og bútum. ${ }^{12}$ Á Íslandi var ekki opnað náttúrugripasafn fyrr en árið 1951 en fram að pví starfrækti Hið islenska Náttúrufreðifélag sýningasafn á ýmsum stöðum í Reykjavík. Nokkuð af gripum safnsins var um árabil til sýnis í Safnahúsinu á Hverfisgötu og svo í sýningarsölum á tveimur hæðum á Hlemmi til ársins $2008 . .^{13}$

Dýrasafn Kristjáns hefur á sínum tíma ef til vill uppfyllt pörf borgarbúa í Reykjavík fyrir nálægð við náttúru og heim dýranna. Á peim tíma sem safnið var rekið voru skilin milli sveita og borgarlífs að skerpast í íslensku samfélagi og við pað verður til einhvers konar tilfinningalegt rof. Ástandinu hefur jafnvel verið lýst sem eins konar tilfinningalegri togstreitu eða samviskubiti borgarbúa yfir pví að hafa yfirgefið sveitina, eins og fjölmargar íslenskar bækur og kvikmyndir fjalla um. ${ }^{14}$ Hvort slíkar tilfinningar hafi látið á sér kræla á meðal safngesta, eða jafnvel verið ein af ástæðum vinsælda Íslenska dýrasafnsins, er kannski ekki ólíklegt. Hvað sem pví líður er ljóst að dýrasafn Kristjáns naut um skeið nokkurra vinsælda og af blaðagreinum að dæma virðist sem pangað hafi verið leitað eftir bæði fræðslu og skemmtan. Í húsinu rak Kristján jafnframt hjónabandsmiðlun um árabil. Leiða má að pví líkum að sumir safngestir hafi ef til vill náð að slá par tvær flugur í einu höggi, með pví að virða fyrir sér bæði dýr og menn, og í sumum tilvikum bindast jafnvel heitböndum. ${ }^{15}$ Óhætt er að segja að í Breiðfirðingabúð hafi margt verið brallað og svo virðist sem dýrasafnið hafi átt ágætis blómaskeið í um fjögur ár en svo hafi tekið að halla undan fæti. Árið 1978 var safnið lýst gjaldprota og voru munir pess og gripir settir á uppboð í Tollstöðvarhúsinu við Tryggvagötu.

Samkvæmt nýlegu samtali mínu við Lýð Pálsson, safnstjóra á Byggðasafni Árnesinga, voru vanskil safnsins vegna gerviaugna víst orðin gríðarhá. Pegar kom að uppboðsdegi læsti forstöðumaðurinn sig inni ásamt safneign-

12 Fjallað er um nokkra slíka safngripi sem Ole Worm sankaði að sér og sýndi meðal annars í fyrrnefndri grein Kötlu Kjartansdóttur um geirfuglinn: Katla Kjartansdóttir, "The changing symbolic meaning of the extinct great auk and its afterlife as a museum object at the Natural History Museum of Denmark“, bls. 41-56.

13 „Saga safnsins“, Náttúruminjasafn Ílands, sótt 29. október 2019 af https://nmsi.is/ saga/.

14 Í pessu samhengi má nefna skáldsöguna 79 af stöðinni (1962) eftir Indriða G. Porsteinsson og kvikmyndina Oðal feðranna (1980) í leikstjórn Hrafns Gunnlaugssonar.

15 „Hjónabandsmiðlun og svæðameðferð“, Morgunblaðið, 30. apríl 1982, bls. 34. 
inni og tók ekki í mál að hleypa nokkrum einasta manni að dýrunum. Á meðfylgjandi mynd sést fulltrúi fógeta og lögreglumaður reyna að brjóta sér leið inn á safnið í gegnum læsta hurð:

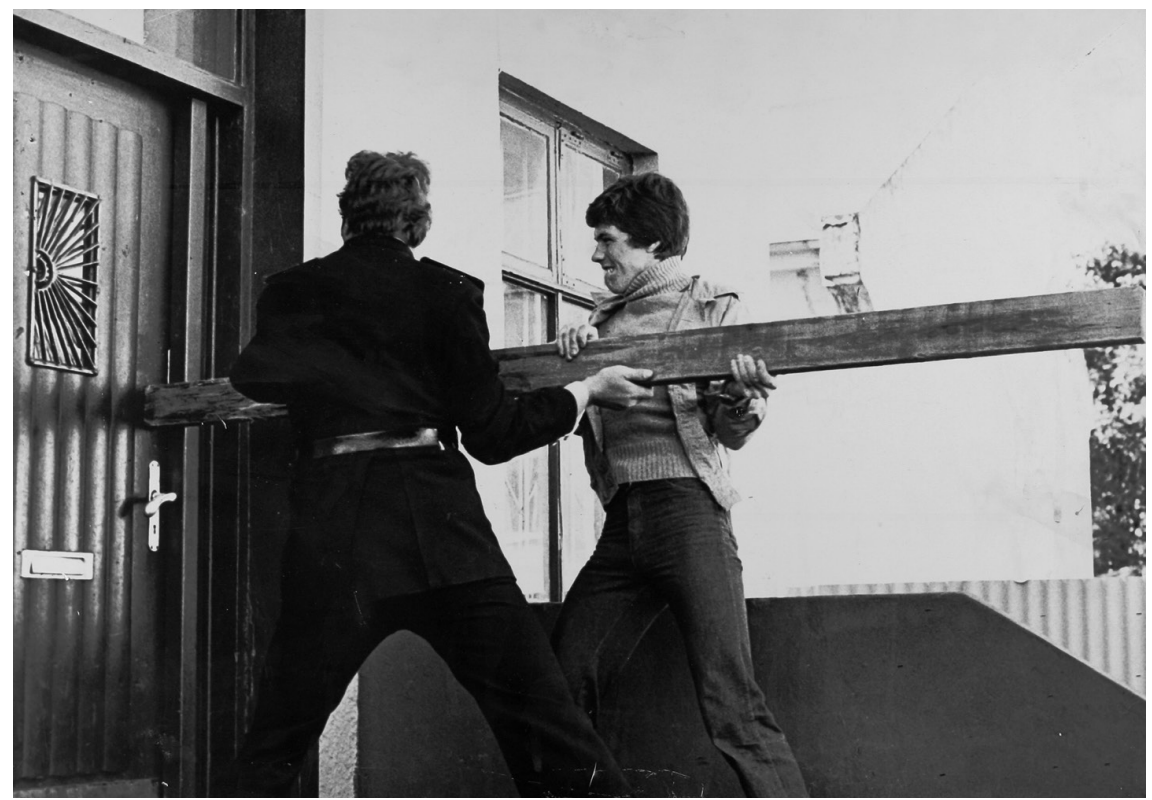

Fulltrúi fógeta og lögreglumaður reyna að brjóta sér leið inn á dýrasafnið í Breiðfirðingabúð. Ljósmyndasafn Reykjavíkur.

Með myndinni, sem birtist á forsíðu Dagblaðsins 2. september 1978, fylgdi eftirfarandi myndatexti: „Ráðizt gegn dyrum Íslenzka dýrasafnsins á gamlan og viðurkenndan hátt.” ${ }^{16}$ Par með lauk að sinni starfsemi pessa merkilega safns í Breiðfirðingabúð á Skólavörðustíg. Flesta munina keypti Byggða- og listasafn Selfoss fyrir um 3,2 milljónir á fyrrnefndu uppboði tollstjórans, en um tvö til prjúhundruð gripir munu hafa verið boðnir upp. ${ }^{17}$

Linda Ásdísardóttir, safnafræðingur og safnvörður á Byggðasafni Árnesinga, segir frá pví í grein sinni í Kvistinum að Byggðasafnið hafi sett upp sýningu á gripunum árið 1980 og var pað pá opnað undir heitinu Dýrasafnið á Selfossi. Samkvæmt Lindu var sýningin vel sótt og rifja Árnesingar enn í dag upp góðar minningar úr safnaheimsókn sinni á Dýrasafnið. Í greininni er einnig greint frá pví að stór hluti uppstoppaðra fugla úr safnkostinum

16 „Lögreglan hér, góðan daginn!“ Dagblaðið, 2. september 1978, bls. 1.

17 „Safnhúsin á Selfossi: Keyptu bróðurpart íslenska dýrasafnsins án pess að fjármagn væri fyrir hendi“, Tíminn, 21. september 1978, bls. 5. 
hafi orðið hluti af sérsýningu byggðasafnsins, par sem færð var saman saga dansks kaupmanns og náttúruverndar. Aðrir gripir úr gamla Dýrasafninu voru hins vegar fluttir í glænýtt geymslu- og pjónustuhús á Eyrarbakka árið $2002 . .^{18}$

\section{Dýrgripir á uppboði}

Samkvæmt samtali mínu við Lýð Pálsson, safnstjóra hjá Byggðasafni Árnesinga, mættu fjórir galvaskir menn úr Árnespingi á sínum tíma á uppboðið hjá Tollstjóra árið 1978 og buðu grimmt í pá gripi sem peim leist best á. Megnið af gripunum voru svo hafðir til sýnis á fyrrnefndu safni, sem fékk heitið Dýrasafnið á Selfossi og var starfrækt frá árinu 1980 til ársins 1995. Samkvæmt Lýð er sumsé töluvert eftir af peim gripum sem keyptir voru á uppboðinu hjá Tollstjóra 1978 en einnig eru dæmi um að munum hafi verið komið fyrir í geymslu eða lánað til annarra safna. Í svokölluðum Eggjaskúr sem tilheyrir Byggðasafni Árnesinga eru til dæmis uppstoppuðu fuglarnir frá Íslenska dýrasafninu enn til sýnis. Stærsti gripurinn úr safninu er ísbjörninn sem var felldur í Fljótavík vorið 1974. Um pessar mundir mun hann vera í millisafnaláni hjá Byggðasafni Vestfjarða á Ísafirði par sem hann sómir sér vel á sýningu. ${ }^{19}$

Á meðal peirra dýrgripa sem fluttust til Selfoss var sumsé uppstoppaði ísbjörninn úr Fljótavík og hryssan Löngumýrar-Skjóna, sem samkvæmt frétt Tímans um málið var „eitt frægasta og umdeildasta hross landsins“ ${ }^{20} \mathrm{Við}$ kaupin sagði Pétur Sigurðsson, safnvörður á Byggða- og listasafni Selfoss, að hann væri sérstaklega ánægður með kaupin á ísbirninum pví pað væri ekki á hverjum degi sem hægt væri að festa kaup á slíkum grip. ${ }^{21}$ Vert er að fjalla nánar um pennan merkilega grip. Bjarndýrið felldi Jón Gunnarsson, smiður á Ísafirði， í Fljótavík á Hornströndum vorið 1974. Í skemmtilegu viðtali lýsir skyttan viðureign sinni við dýrið. Hann segir svo frá að hann og félagar hans hafi verið, auk priggja krakka, staddir í gistiskýlinu í Fljótavík pegar peir urðu varir við eitthvað óvenjulegt fyrir utan skýlið. Рað reyndist pá vera bjarndýrið sem farið var að gæða sér á nestinu, sem geymt var úti.

18 Linda Ásdísardóttir, „Ugla sat á Kvisti“, Safnablaðið Kvistur 1/2016, bls. 8-11.

19 Tölvupóstsamskipti við Lýð Pálsson safnstjóra Byggðasafns Árnesinga, 29. nóvember 2019.

20 Safnhúsin á Selfossi: Keyptu bróðurpart íslenska dýrasafnsins án pess að fjármagn væri fyrir hendi“, Tíminn, 21. september 1978, bls. 5 .

21 Sama heimild, bls. 5 . 
Jón lýsir pví sem svo að dýrið hafi verið í klappfæri við pá og að peir hafi nötrað af hræðslu. Peir töldu ekki ólíklegt að björninn myndi brjóta upp hurðina og éta pá upp til agna. Umræður hófust pá um pað hvað skyldi til bragðs taka, hugmyndir voru uppi um að bregða neti yfir dýrið en skjótt varð niðurstaðan sú að ná í skotfæri. Stuttu síðar lá björninn allur á flötinni fyrir framan gistiskýlið. ${ }^{22}$

Eftir petta tók Kristján S. Jósefsson dýrið til varðveislu og Jón M. Guðmundsson stoppaði pað upp. Um skeið var pað svo til sýnis hjá honum í dýrasafninu í Breiðfirðingabúð eða par til kom að gjaldproti. Pá var hvítabjörninn, sem fyrr segir, fluttur til Selfoss ásamt öðrum munum og gripum úr safni Kristjáns. Á mynd sem fylgir fréttinni má sjá uppstoppaða björninn standa, eins og tekið er fram í myndatexta, keikan á safninu í Selfossi. Ekki er annað að sjá en hann uni par hag sínum vel. ${ }^{23}$ Enginn vafi leikur á pví að dýrasafnið hafði í sinni safneign ýmsa óvenjulega og sjaldgæfa gripi, til viðbótar við ísbjörninn var par til dæmis einnig að finna tvíhöfða lamb sem, eftir nokkra eftirgrennslan, er nú varðveitt á Draugasetrinu á Stokkseyri gestum til hrellingar. ${ }^{24}$

Annar merkilegur gripur var einnig um skeið varðveittur hjá íslenska dýrasafninu. En pað er hinn víðfrægi uppstoppaði api sem Ellý Vilhjálmsdóttir, söngkona, átti lengi vel. Apinn varó á sinni tíð allvel pekktur undir nafninu Bongo. Í frétt Ríkisútvarpsins segir frá pví með hvaða hætti apinn komst í hendur Ellýar í Spánarferð en samkvæmt vinkonu, sem var með henni í för, valdi Ellý Bongo vegna pess að hann var gáfulegastur af peim til augnanna. Fylgdi Bongo síðan Ellý um langt skeið og varð hann nokkuð frægur í Blómaskála Mikkelsen í Hveragerði. Eftir stutta dvöl par var hann stoppaður upp og sendur á dýrasafnið til Kristjáns Jósefssonar. Árið 1978 fréttist svo af apanum á uppboði hjá tollstjóra og talið var að hann hefði verið keyptur ásamt öðrum munum af Byggðasafni Árnesinga. Við eftirgrennslan kom hins vegar í ljós að hann var að finna í Menntaskólanum á Laugarvatni, par sem hann er víst enn. Samkvæmt fréttinni var Bongo mikill skemmtikraftur, en með eindæmum afbrýðisamur og illa lyktandi í pokkabót. ${ }^{25}$

22 „Dýrið lá fyrir framan dyrnar og át nestið mitt“, Dagblaðið Visir, 20. febrúar 1988, bls. 18 .

23 „Björninn er hýstur á Selfossi“, Dagblaðið Visir, 20. febrúar 1988, bls. 18.

24 Tölvupóstsamskipti við Lýð Pálsson safnstjóra Byggðasafns Árnesinga, 29. nóvember 2019.

25 „Api Ellýar fundinn“, RÚV, 9. nóvember 2012, sótt 29. október 2019 af https:// 
Hér er áhugavert að sjá hvernig apanum er gefið mannlegt yfirbragð og eiginleikar. Honum er í raun lýst eins og um manneskju sé að ræða en ekki dýr. Í pessu samhengi hafa fræðimenn á borð við Hillevi Ganetz rætt um pað hvernig manneskjan eigi pað til að yfirfæra mannlega eiginleika, tilfinningar og gildi yfir á önnur dýr. Um eins konar manngervingu er pá að ræða (e. antropomorphism) og nefnir Ganetz velpekkt dæmi úr Disney kvikmyndum á borð við Bamba par sem dádýrinu eru gefnir mannlegir eiginleikar og skapgerð. Var petta einkum gert, samkvæmt Walt Disney sjálfum, til pess að áhorfendur ættu pá betur með að finna til samkenndar með dýrinu. ${ }^{26}$ Fjölmörg dæmi af pessu tagi mætti auðvitað nefna úr kvikmyndum, en ekki síður úr pjóðsögum og ævintýrum. Í sumum sögum ná tiltekin dýr jafnvel að komast svo langt inn fyrir mörk pess mannlega að ástir kvikna, pvert á tegundir. Í slíkum tilvikum er pó reyndar oft um álög að ræða, sem einungis er hægt að aflétta með kossi frá réttum aðila. Á pað til dæmis við um svaninn fagra sem Dimmalimm gaf koss í Evintýrinu um Dimmalimm, en hann reyndist pá vera prins í álögum. ${ }^{27}$ Viðlíka álög eru einnig uppi á teningnum í Disneyævintýrinu um Fríðu og Dýrið og fleiri ævintýrum og sögum, sem ekki verða nefndar hér. Hvort suðræni apinn Bongo sé ef til vill prins í álögum er ekki enn komið í ljós.

\section{Lokaorð}

Í Morgunblaðinu árið 1979 er greint frá pví að „á mínútunni klukkan tvö laugardaginn 1. september“28 muni íslenska dýrasafnið opna á ný. Jafnframt er að pessu tilefni haft eftir Kristjáni S. Jósefssyni, forstöðumanni safnsins, að einmitt pá muni vera „nákvæmlega eitt ár liðið frá pví menn borgarfógeta komu í Breiðfirðingabúð og tóku öll dýrin [hans] upp í skattaskuld“.29 Pá tekur Kristján pað sérstaklega fram að hann hafi nú náð hluta af dýrunum sínum tilbaka frá Selfossi, par á meðal Löngumýrar-Skjónu en einnig að hann hafi náð að útvega nokkuð af nýjum dýrum, til dæmis fimm vetra gamlan bolakálf. Með fréttinni fylgir síðan ljósmynd af stoltum forstöðumanninum við hlið kálfsins, sem virðist líkt og Kristján bara nokkuð sáttur

www.ruv.is/frett/api-ellyjar-fundinn.

26 Hillevi Ganetz, „Familiar Beasts: Nature, Culture and Gender in wildlife films on television“, Nordicom Review 1-2/2004, bls. 197-213.

27 Evintýrið samdi Muggur og myndskreytti árið 1921 fyrir litla frænku sína.

28 „Íslenska dýrasafnið opnar á ný. Eitt ár liðið síðan fógeti hirti safngripina upp í skuld“, Morgunblaðið, 30. ágúst 1979, bls. 8.

29 Sama heimild, bls. 8. 
við pessi málalok. Að endingu er svo greint frá pví að safnið muni sem fyrr verða til húsa í Breiðfirðingabúð. ${ }^{30}$

Í dag er hins vegar Snorrabúð stekkur og pví miður ekkert dýrasafn lengur á Skólavörðustíg en slíkt safn ætti auðvitað mjög vel heima til dæmis í gamla Hegningarhúsinu. Saga íslenska dýrasafnsins er að mörgu leyti mjög merkileg. Í fyrsta lagi ber hún vitni um mikla prautseigju og eldhug forstöðumannsins, Kristjáns S. Jósefssonar, sem lét ekki deigan síga pó stundum gæfi á bátinn. Framlag hans til menningar- og bæjarlífs Reykjavíkur á áttunda áratugnum tel ég ótvírætt. Saga safnsins sýnir einnig að margir dýrgripir, á borð við hvítabjörninn sem skotinn var í Fljótavík vorið 1974, hafa góðu heilli fengið par húsaskjól, varðveislu og ágætis framhaldslíf í formi uppstoppaðra muna. Pessir safnmunir virðast hafa nýst prýðilega og vakið bæði forvitni og skemmtan meðal bæjarbúa. Af umfjöllun fjölmiðla að dæma virðist sem safnið hafi notið vinsælda og verið jafnframt nokkuð vel nýtt sem námsvettvangur, fyrir jafnt blinda sem sjáandi. Hvort safnið hafi almennt haft meira skemmtigildi umfram fræðslugildi skal hins vegar ósagt látið.

30 Sama heimild, bls. 8 . 